\title{
Using electronic application for monitoring animals in protected areas on the example survey 123
}

\author{
NR Pirtskhalava-Karpova ${ }^{1,2}$, AA Karpov ${ }^{1}$, DA Barashnin ${ }^{1,3}$ \\ 1 Northern (Arctic) Federal University named after M.V. Lomonosov (Arkhangelsk, Russia) \\ 2 Kurilskiy Nature Reserve (Sakhalin region, Russia) \\ 3 Russian Arctic National Park (Arkhangelsk, Russia)
}

Corresponding author: Nana R. Pirtskhalava-Karpova (heynanabl@gmail.com)

Academic editor: Aleksandr I. Malov • Received 23 August 2020 • Accepted 12 November 2020 Published 25 January 2021

Citation: Pirtskhalava-Karpova NR, Karpov AA, Barashnin DA (2021) Using electronic application for monitoring animals in protected areas on the example survey 123. Arctic Environmental Research 21(1): 1-7. https://doi.org/10.17238/issn2227-6572.2021.21.1.1

\begin{abstract}
Monitoring of the animal world is an important component in the development of world science. Observations of animals in specially protected nature areas are conducted year-round. The goal of the study was to develop electronic data collection forms for Survey123 used for ArcGIS application and to collect field data using this application tested during the field seasons 2018-2019 in the National Park Russian Arctic. Monitoring of the number of Arctic animals (white bears, walruses, seals, etc.) was carried out from the marine vessel and along the walking routes during the polar day by the state inspectors of the Russian Arctic National Park. The results of the application testing were the animal counting field data in electronic format taken during one flight of the 50 Years of Victory icebreaker, on the vessel "Altai" and during three flights of the Sea Spirit vessel. The total number of mammals obtained using the application during the 2018-2019 field seasons was 3,452 individuals, and the total number of birds was 14,457. All animal encounters are referenced by coordinates and presented on the electronic map. The Survey123 application testing during the 2018-2019 field seasons showed the efficiency of collecting animal data in electronic format which makes the data immediately available for processing and analysis. At the end of the field seasons, it was concluded that the electronic application can completely replace the hand-written register of animals.
\end{abstract}

\section{Keywords}

animal monitoring, animal counting, biomonitoring, specially protected nature areas, Survey123

Copyright Pirtskhalava-Karpova NR et al. This is an open access article distributed under the terms of the Creative Commons Attribution License (CC.BY 4.0), which permits unrestricted use, distribution, and reproduction in any medium, provided the original author and source are credited. 


\section{Introduction}

Rapidly disappearing white bears as well as others species of animals list on the Red book, course alward a man ecologically away people in the world. The conservation of the number of wild animals, in particular, animals listed on the Red Book, the control of invasive species in new habitats and the importance of biodiversity for maintaining the normal functioning of natural ecosystems are priority areas around the world.

Counting of animals is performed by state inspectors in specially protected nature areas and by forestry workers. Work on the animals counting is carried out along the certain route on foot or using technical means, such as ships or aircraft. On the route, all the encountered animals and animal tracks are recorded. Whereas, registration of animals is done manually or on paper. For more effective work, you can use the electronic application for the registration of animals. Monitoring of the distribution of animals and their numbers is carried out mainly in the summer months and from icebreakers or sea vessels. The traditional method of keeping records is to fill in the journal for animal counting. The paper format of data collection makes it difficult to further process data and analyze them. The solution to this problem is to use applications that allow you to collect data electronically with automatic determination of geographic coordinates by Global Positioning System (GPS) for the data collection point. One of these electronic applications is the Survey123 developed by ESRI (Survey123 for ArcGIS). The application is universal and can be used in any field, as it allows you to create your own form with certain fields where the collected data will fit.

Currently, there are various techniques for animals counting, developed by the leading scientists. For example, there is a methodology developed for monitoring of the Kamchatka brown bear by Valentsov (2002) conducted by the method of aerial accounting. This methodology includes several stages: monitoring of living conditions, monitoring of population and numbers, monitoring of population structure, fertility and reproduction of resources, and others. Professor Chelintsev (2017) developed several methods of animal counting: an estimate of the number of seals using the ship transect counting method using extrapolation, as well as an aerial survey of white bears. The first method is carried out using shipboard counting. Krasnov (2000) developed a methodological basis for counting of seabirds in the Northern seas. Marine vessels are most commonly used in the high seas as a research platform for bird watching. Aircraft is less often used for observations, mainly due to the high cost of the flight hour. Remote sensing methods are less likely used, in particular, loggers (geolocators) and satellite sensors which allow to identify specific migration routes of birds, their feeding areas, migration, molting, wintering, and breeding sites.

In Russia, in the areas with a stable snow cover, a comprehensive method of winter route counting (WRC) is widely used to count many types of hunting animals and birds. A significant contribution to the WRC methodology was made by such scientists as Formozov (1951), Belikov (1984), Chesmore (2001), Buckland (2001), Johnson (2004), Semenova (2011), Neeraj (2012), Yu (2013). Today we have a very efficient WRC methodology, including biological, geographic, organizational, technical, mathematical, and software-calculated aspects.

There are also many scientific studies on the subject of automation and simplification of counting of wild animals aimed at using unmanned aerial vehicles, high-resolution satellite imagery and photo traps for monitoring of the numbers of animals. For example, photos of animals captured by camera traps can be automatically identified using neural networks and machine learning, i.e. they can automatically take animals into account (Gomez 2016; Guignard 2016). Also, such a significant contribution to the monitoring of the animal world was made by such scientists as Medvedev (2015) and Karpenko (2015), Monitoring of Wildlife in Specially Protected Natural Areas Using Unmanned Aircraft Systems. High-resolution satellite images can also be used for the monitoring of marine mammals and for the white bear particularly (Stapleton et al. 2014; LaRue et al. 2011).

In the number of countries, in particular, in Norway, bird counting is included in the national special-purpose bird research programs in the high seas and oceans. The results of the Norwegian bird distri- 
bution program in the Greenland and Barents seas were reflected in the final publications in 1980-2018.

There are international societies that monitor wildlife. One striking example of such a community is the site ebird.org which brings together birdwatchers all over the world. The idea of this project is to combine birdwatching throughout the world on one site. All observations are made according to a common methodology, and both professionals and amateurs participate in them.

At the same time, monitoring studies are carried out not only by scientific institutions, but also by structures of state bodies, which, in accordance with the Law on the Protection, Reproduction and Use of Wildlife and the Law on Specially Protected Nature Territories, are assigned such responsibilities, in particular, protected areas personnel (The Federal Law of the Russian Federation of March 14, 1995).

Under the Convention on Biological Diversity, 2010, many countries have pledged to reduce biodiversity loss by 2020 (Secretariat of the Convention on Biological Diversity 2010). An understanding of biodiversity trends should be based on the quantitative assessment that previously was carried out only in small areas. Wildlife monitoring programs should include the following items:

1. information on the status of wildlife populations;

2. evaluate the effectiveness of management actions;

3. provide feedback to understand the correctness of the environmental approach as a whole.

The main goal of the study is to collect data using an electronic application for counting of animals on the territory of the protected areas in order to create a geographic information system in the future which is based on the collected data and introduce the developed technologies into the protected area activities in the field of animal monitoring.

\section{Materials and methods}

The Russian Arctic National Park was chosen as the place for the experiment of the application form for animal monitoring used in the protected areas. The national park is located on two polar archipelagos in the Arkhangelsk region: Novaya Zemlya and Franz Josef Land. The territory of the park is a place of habitat animals listed on the Red Book species such as the white bear, the Atlantic walrus, the Greenland whale, the narwhal, the Novaya Zemlya reindeer, the white gull, and the Atlantic black brant inhabit the territory of the Russian Arctic Park. In addition to these species, the park has the following animals: the ringed seal, the harp seal, the sea hare, the white whale, and the birds include several species of skuas, the Lurik, the thick-billed murre, burgomasters, warriors, and other animals. To account for and conserve Arctic species of mammals, electronic forms have been developed to account for animals.

The development of electronic forms for the registration of animals includes a structured system for collecting information. The data collection form in the appendix contains the drop-down lists of animal species typical for the territory of the Russian Arctic National Park. Information obtained during the observation of mammals and birds has entered in the categories "animal species", "sex", "age", "animal color", "animal activity", "fatness". In addition, the weather information "temperature", "ice conditions", "precipitation" must be indicated. A very important category is "location". This is indicated automatically. This information is very important because it is used to calculate the movement of animals. These criteria were projected to describe mammals. For each species, a brief description was made and a photo was attached simplifying the identification of the species of animals that is especially important for birds. The use of electronic forms for the registration of mammals is a trend for work in specially protected natural areas. Electronic forms of animal records contain structured categories for collecting information. This can completely replace paper accounting forms.

The developed electronic forms for the registration of mammals are uploaded to the Servey 123 program. The Survey 123 program is used to efficiently collect information about animals and further process the results. This application is provided by the company ESRI. Survey123 was installed on the mobile phone and the tablet equipped with GPS modules. One device was sent for animal counting on the 
board of the 50 Years of Victory icebreaker traveling along the route Murmansk - Franz Josef Land - North Pole. Another device was used on the board of the Sea Spirit vessel and the vessel "Altai" cruising the islands of Franz Josef Land. In addition to the application Survey123, the devices were also provided with the applications for the tracking of the vessel.

\section{Results}

The results of the application testing were the field data on animal counting in the electronic format from one flight of the 50 Years of Victory icebreaker with a length of 3,091 nautical miles and three trips of the Sea Spirit vessel with a total length of 4,071 nautical miles, trips of the Altai vessel with a total length of 3,081 nautical miles. The total number of mammals recorded using the application during the 2018-2019 field seasons was 3,452 individuals and 14,457 birds (Tables 1, 2).

Table 1. Animals counted during the 2018 field season (In the territory of the national park)

\begin{tabular}{lccc}
\hline Biological species & Quantity, pieces & Biological species & Quantity, pieces \\
\hline Walrus & 549 & Little Auk & 671 \\
White Whale & 100 & Kittywake & 617 \\
Polar Bear & 45 & Bearded Seal & 7 \\
Glaucous Gull & 125 & Narwhal & 7 \\
Common Eider & 397 & Arctic Fox & 5 \\
King Eider & 1 & Purple Sandpiper & 7 \\
Northern Fulmar & 310 & Great Skua & 2 \\
Bowhead Whale & 51 & Long-Tailed Skua & 49 \\
Harp Seal & 5 & Arctic Skua & 40 \\
Brant Goose & 29 & Pomarine Skua & 2 \\
Brunnich's Guillemot & 1550 & Snow Bunting & 2 \\
Guillemot & 10 & Atlantic Puffin & 4 \\
Ringed Seal & 52 & Ivory Gull & 61 \\
Red-Throated Diver & 2 & Great Black- & 50 \\
& & Backed Gull & \\
Arctic Tern & 4 & Black Guillemot & 278 \\
\hline
\end{tabular}

All the encounters with animals are associated with geographic coordinates and presented on the electronic map available at https://rusarctic.maps.arcgis. com/apps/webappviewer/index.html?id=dfa3f3bff1974c999c201ala510fbd8c. The map also contains digitized data of the 2018 and 2019 field seasons. The
Table 2. Animals counted during the 2019 field season (In the territory of the national park)

\begin{tabular}{lccc}
\hline Biological species & Quantity, pieces & Biological species & Quantity, pieces \\
\hline Walrus & 2222 & Kittywake & 4064 \\
White Whale & 36 & Bearded Seal & 34 \\
Polar Bear & 85 & Purple Sandpiper & 8 \\
Glaucous Gull & 137 & Narwhal & 2 \\
Sabin's Gull & 1 & Unindentified Whale & 12 \\
Northern Bottlenose & 1 & Unindentified Skua & 7 \\
Whale & & & \\
Common Eider & 220 & Unindentified Seal & 7 \\
Northern Fulmar & 1910 & Unindentified Baleen & 4 \\
& & Whale & \\
Humpback Whale & 20 & Arctic Fox & 8 \\
Bowhead Whale & 63 & Great Skua & 7 \\
Harp Seal & 54 & Long-Tailed Skua & 13 \\
Brant Goose & 82 & Arctic Skua & 151 \\
Brunnich's Guillemot & 1097 & Pomarine Skua & 51 \\
Guillemot & 11 & Snow Bunting & 20 \\
Ringed Seal & 82 & Atlantic Puffin & 4 \\
Red-Throated Diver & 10 & Ruff & 1 \\
Arctic Tern & 78 & Ivory Gull & 116 \\
Little Auk & 1251 & Great Black-Backed & 2 \\
& & Gull & \\
Minke Whale & 1 & Black Guillemot & 571 \\
\hline
\end{tabular}

application interface for animal counting and recording of weather conditions is shown in Figure 1.

Figure 2 shows the map of the encounters with white bears during the 2018 field season.

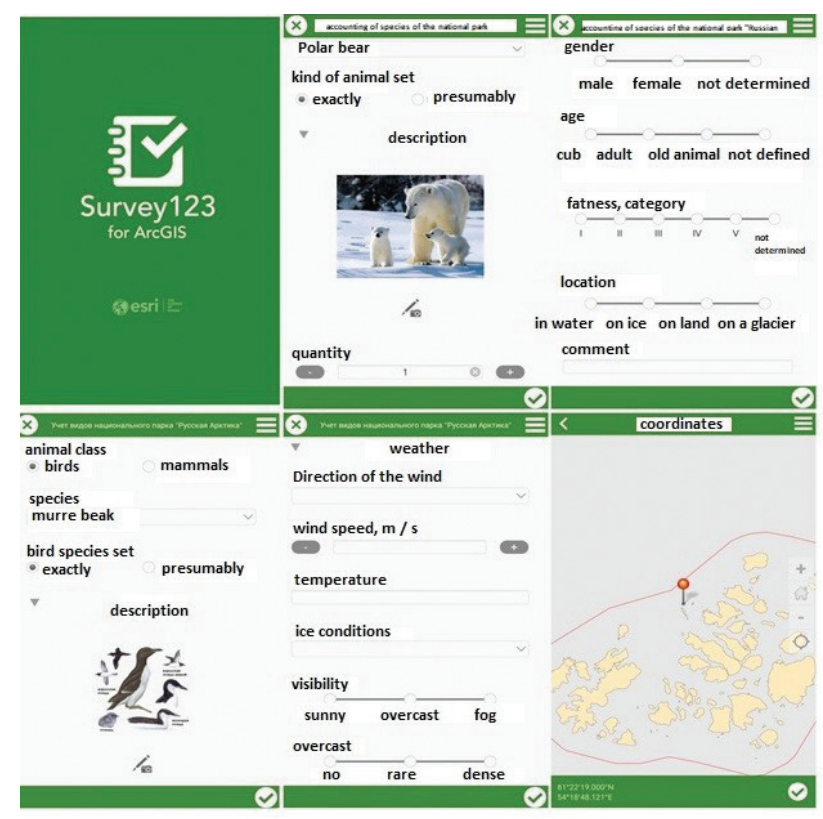

Figure 1. The interface of the animals counting form and weather conditions records. 


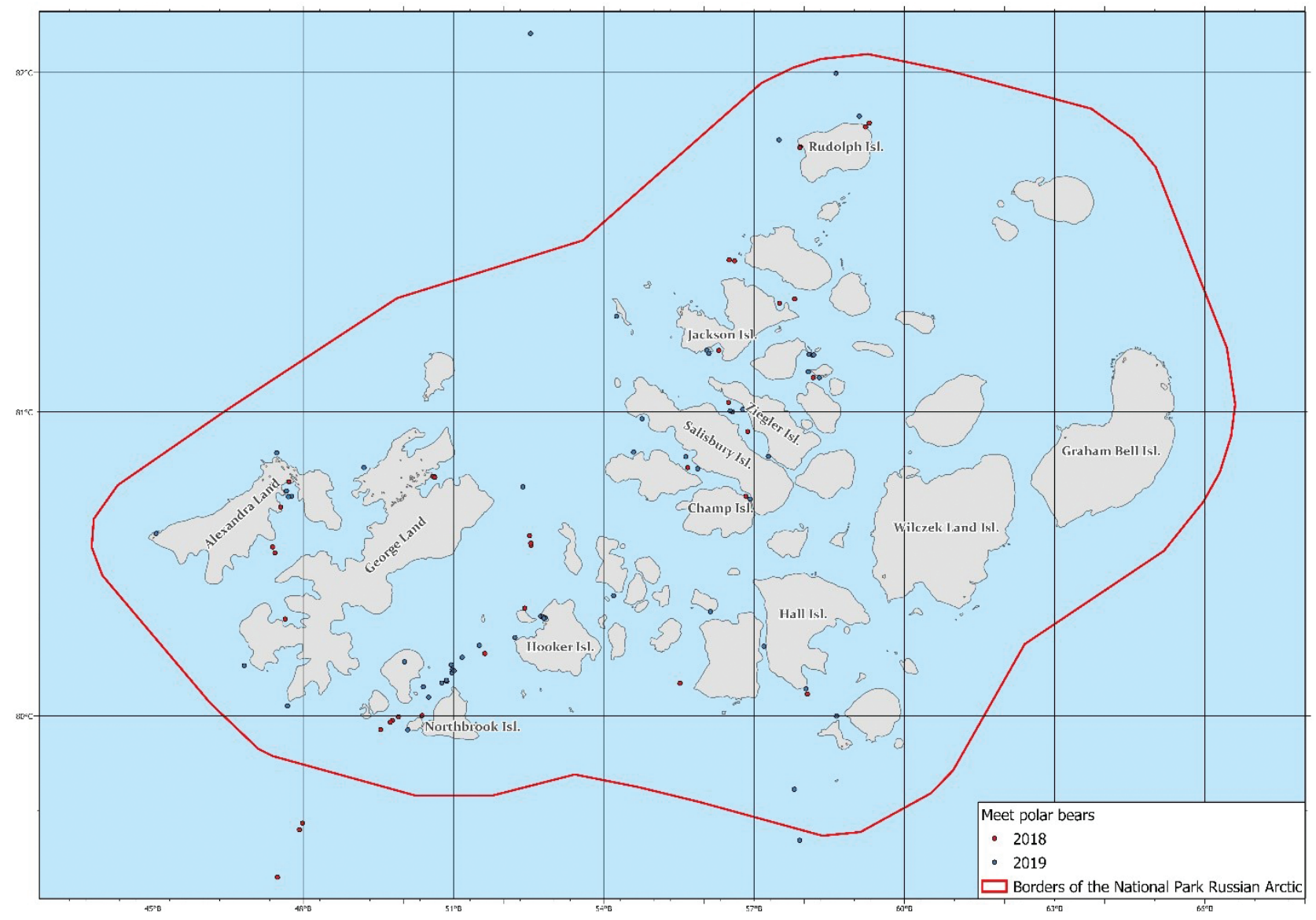

Figure 2. Map of the encounters with white bears during the 2018-2019 field seasons

\section{Discussion}

Using an electronic application for performing animal registration has a number of advantages. Digital data are ready for analysis of the collected information. Collection data in digital type allows to have maximum control over the activities of state inspectors of protected areas for account of animals. Analyzing the data obtained, it is possible to track the number of observations made by each inspector, which is an indicator of the effectiveness of its work. Using the application makes impossible to enter "false" data to ensure the execution of the work plan. The application interface for animal counting and recording of weather conditions is shown in Figure 1.

Implementation of such a system of animal records should lead to improved quality of animal observa- tions. The accumulation of long-term data in digital form can use for analysis of biodiversity assessment for the territories in the future. The collected data have geographic coordinates for each observation. It allows to use these data for further spatial analysis in conjunction with other spatial data sets to identify the dependencies and relationships between various biotic and abiotic factors, anthropogenic influence on the ecosystems of the research area and the impact of climate change on this area.

Aims of this article are demonstrating the possibility of using modern technologies in protected areas for the registration of animals. It can increase the efficiency of work in this area and control over the implementation of these works. The using Survey 123 application is not required additional financial costs for protected areas. The ESRI provides environmen- 
tal organizations with its software free of charge under a grant. This application will be interesting for foresters, who do winter routes for accounting animals and other types of animal accounting, non-governmental environmental organizations.

Testing of the Survey123 application during the 2018-2019 field seasons showed the efficiency of collecting animal data in the electronic format that makes the data immediately available for processing and analysis. According to the results of the field season, it was concluded that the electronic application can completely replace the hand-written $\log$ of animals.

\section{Conclusion}

Testing of the Survey123 application during the 20182019 field seasons showed the efficiency of collecting animal data in the electronic format that makes the data immediately available for processing and analysis. In the future the electronic application can completely replace the hand-written log of animals. This application can replace manual journal filling. After the development of the application and its testing in several specially protected natural areas of Russia, it will be proposed to introduce this development into the activities of protected areas on monitoring the wildlife.

This application may be relevant for all specially protected nature areas, forest areas and for environ-

\section{References}

- Belikov SE, Gorbunov YuAShil'nikov VI (1984) Distribution and Migrations of Some Pinnipeds, Cetaceans, and White Bears in the Seas of the Eastern Arctic Region. Morskie mlekopitayushchie, 233-252. [In Russian]

- Buckland ST, Anderson DR, Burnham KP, Laake JL, Borchers DL, Thomas L (2001) Introduction to Distance Sampling: Estimating Abundance of Biological Populations. Oxford University Press, $432 \mathrm{pp}$.

- Chelintsev NG, Goryaev YuI, Ezhov AV, Makarevich PR, Ishkulov DG (2017) Experience in estimating the number of seals by ship transect accounting using sector extrapolation mental surveys in the field of animal counting at the sites of licensed mining operations. The application will allow to unify and structure the collected information, accumulate data, uploading it to an electronic database. Use of a smartphone with a GPS module will simplify data collection for experts involved in the monitoring of the animal world. The created geographic information system will allow them to review, analyze and create reports on the collected data.

The accumulation of electronic data in the geographic information system will allow to carry out a spatial-temporal analysis of data that will allow to estimate the number of animals more accurately and assess the effects of various factors on them more qualitatively. The implementation of electronic applications for activities on the protected natural territories and for use in different organizations will improve the quality of collected materials, simplify data collection, provide the ability to receive timely information and to control remote animal monitoring, and also improve the quality of management decisions.

\section{Acknowledgments}

We are very grateful National Park Russian Arctic for the logistical support and the provided base for testing animal monitoring forms for the application Survey 123 . We thank ESRI for the grant in the form of software ArcGIS for specially protected natural areas.

based on observations in the southwestern part of the Kara Sea in the summer of 2015 [Opyt otsenki chislennosti tyuleney metodom sudovogo transektnogo uchota s primeneniyem sektornoy ekstrapolyatsii po rezul'tatam nablyudeniy $\mathrm{v}$ yugozapadnoy chasti Karskogo morya v letniy period 2015]. Vodnyye biologicheskiye resursy. Trudy VNIRO 168: 117124. [In Russian]

- Chesmore ED (2001) Application of Time Domain Signal Coding and Artificial Neural Networks to Passive Acoustical Identification of Animals. Applied Acoustics 62(12): 13591374. https://doi.org/10.1016/S0003-682X(01)00009-3 
Formozov AN (1951) Quantitative method in zoogeography of terrestrial vertebrate species and transformational changes of the USSR nature Kolichestvennyi metod v zoogeografii nazemnykh pozvonochnykh zhivotnykh i zadachi preobrazovaniya prirody SSSR [Quantitative method in zoogeography of terrestrial vertebrate species and transformational changes of the USSR nature]. Izvestiya AN SSSR 2: 62-70. [In Russian]

- Gomez A, Salazar A (2016) Towards automatic wild animal monitoring: Identification of animal species in camera-trap images using very deep convolutional neural networks. arXiv preprint arXiv:1603.06169.

- Guignard L, Weinberger N (2016) Animal identification from remote camera images. CS231A Class Project, 4 pp.

- Johnson CJ, Gillingham MP (2004) Mapping Uncertainty: Sensitivity of Wildlife Habitat Ratings to Expert Opinion. Journal of Applied Ecology 41(6): 1032-1041. https://doi. org/10.1111/j.0021-8901.2004.00975.x

- Krasnov YuV, Barret RT (2000) Monitoring of seabirds in the Barents Sea. Program offer [Monitoring morskikh ptits v Barentsevom more. Programmnoye predlozheniye]. Russkiy ornitologicheskiy zhurnal 113:3-22. [In Russian]

- LaRue MA, Rotella JJ, Garrott RA, Siniff DB, Ainley DG, Stauffer GE, Porter CC, Morin PJ (2011) Satellite Imagery Can Be Used to Detect Variation in Abundance of Weddell Seals (Leptonychotes weddelli) in Erebus Bay, Antarctica. Polar Biology 34(11): 1727-1737. https://doi.org/10.1007/ s00300-011-1023-0

- Medvedev AA, Alekseenko NA, Karpenko IO (2015) Monitoring of Wildlife in Specially Protected Natural Areas Using Unmanned Aircraft Systems [Monitoring zhivotnogo mira na osobo okhranyaemykh prirodnykh territoriyakh $s$ pomoshch'yu bespilotnykh letatel'nykh apparatov]. Izvestiya Samarskogo nauchnogo tsentra RAN 17(6): 304-309. [In Russian]

- Neeraj K, Belhumeur PN, Biswas A, Jacobs DW, Kress WJ, Lopez IC, Soares JVB (2012) Leafsnap: A computer vision system for automatic plant species identification. European Conference on Computer Vision, 502-516. https://doi. org/10.1007/978-3-642-33709-3_36
- Secretariat of the Convention on Biological Diversity (2010) Secretariat of the Convention on Biological Diversity. Global Biodiversity Outlook. Version 2010. https://www.cbd.int/doc/ gbo/gbo2/cbd-gbo2-en.pdf [Accessed 2019 November 3]

- Semenova VS, Knizhnikov AYu, Boltunov AN, Evtushenko NV (2011) Study of the Population of Atlantic Walrus in the Barents Sea with the Aid of Space Technologies [Izuchenie populyatsii atlanticheskogo morzha $\mathrm{v}$ Barentsevom more $\mathrm{s}$ pomoshch'yu kosmicheskikh tekhnologiy]. Zemlya iz kosmosa: naibolee effektivnye resheneniya 10: 89-90. [In Russian]

- Stapleton S, LaRue M, Lecomte N, Atkinson S, Garshelis D, Porter C, Atwood T (2014) Polar Bears from Space: Assessing Satellite Imagery as a Tool to Track Arctic Wildlife. PLoS ONE 9(7): e101513. https://doi.org/10.1371/journal.pone.0101513

- Survey123 for ArcGIS (2019) Survey123 for ArcGIS. https:// doc.arcgis.com/ru/survey123/desktop/create-surveys/createsurveys.htm [accessed 20 May 2019]

- The Federal Law of the Russian Federation of March 14, 1995 (2000) The Federal Law of the Russian Federation of March 14, 1995 "On Specially Protected Nature Territories of the Russian Federation”. Sbornik rukovodyashchikh dokumentov po zapovednomy delu [Collection of guiding documents on reserve management and studies]. Moscow, 20 pp. [In Russian]

- Valentsev AS, Voropanov VYu, Gordienko VN, Lebedko AV (2002) Monitoring and population management of brown bears in Kamchatka [Monitoring i upravlenie populyatsiey burgoo medvedya na Kamchatke]. Sovremennye problemy prirodopolzovaniya, okhotovedeniya i zverovodstva: Materialy mezhdunar. nauch.-praktich. konf., posvyashchennoi 80-letiyu VNIIOZ (28-31 maya 2002 g.) [Modern Problems of Nature Management, Game Management and Animal Breeding: Materials of the International Research and Practice Conference dedicated to $80^{\text {th }}$ Anniversary of All-Russian Research Institute for Hunting Husbandry and Livestock Breeding (28-31 May, 2002)]. Kirov, 168-170. [In Russian]

- Yu X, Wang J, Roland K, Jansen PA, Wang T, Huang T (2013) Automated Identification of Animal Species in Camera Trap Images. EURASIP Journal on Image and Video Processing, 2013(1): 1-10. https://doi.org/10.1186/1687-5281-2013-52 